\title{
Taxonomy confirmation of Puntius cf. binotatus from Gunung Tujuh Lake, Jambi, Indonesia based on Cytochrome Oxidase-I (COI) gene
}

\author{
DEWI IMELDA ROESMA", DJONG HON TJONG, WILA KARLINA, DYTA RABBANI AIDIL \\ Department of Biology, Faculty of Mathematics and Natural Sciences, Universitas Andalas. Jl. Universitas Andalas, Limau Manih, Pauh, Padang \\ 25163, West Sumatra, Indonesia. Tel. +62-751- 777427. Fax.+62-751-71343, `email: dewiroesma@ sci.unand.ac.id.
}

Manuscript received: 21 September 2018. Revision accepted: 2 December 2018.

\begin{abstract}
Roesma D. I, Tjong D. H, Karlina W, Aidil D. R. 2019. Taxonomy confirmation of Puntius cf. binotatus from Gunung Tujuh Lake based on Cytochrome Oxidase-I (COI) gene. Biodiversitas 20: 54-60. The population of Puntius cf. binotatus Gunung Tujuh Lake in considered as an isolated population which found in the 20-30 meters depth under the water Gunung Tujuh Lake, Sumatra Island. The species often exhibit different phenotypic characters and may genetic characters may also different due to their response to habitat/ecological conditions. Previous study on P. binotatus from several locations in West Sumatra showed the complexity of the genetic and morphological characters. A molecular study using COI gene of $P$. cf. binotatus from Gunung Tujuh Lake in Sumatera has been conducted to determine the taxonomic status of the fish. The distinct morphological characters of Puntius cf. binotatus is one black spot in the middle of the caudal and the absent of black spot on the base of the anterior dorsal ray. The analysis on COI gene showed that the range of sequence divergences between P. cf. binotatus Gunung Tujuh Lake and other Sumatra P. cf. binotatus is 3.1-7.6\% and $4.1 \%$ to Barbodes banksi. This value represents the differences at the subspecies level of Barbodes banksi. Therefore Barbodes banksi gunungtujuh is proposed as an appropriate name to $P$. cf. binotatus Gunung Tujuh Lake.
\end{abstract}

Keywords: Morphology, Cyt b gene, COI gene, Gunung Tujuh Lake, Puntius cf. binotatus

\section{INTRODUCTION}

Gunung Tujuh Lake, Kerinci District, Jambi Province is located in Sumatra Island, Indonesia at an altitude of 1,950 meters above sea level, surrounded by volcanic mountains that have seven peaks. There is no river flow into the lake as the water source for the lake, except for water catchment surrounding that entering the lake through the small rivers. Water flows out of the lake directly forming a 75 meters high waterfall. It is believed that the fish live in this lake have been isolated for a long period. It has been proven that the population in perfectly isolated habitats that prevent the migration of individuals between populations. If there is limited gene flow between populations, the frequency of genes in a population will be different from before, in which the genetic mixing between populations still occur (Roesma et al. 2017). Handika et al. (2014) reported that there is a type of fish with genus Puntius in Gunung Tujuh Lake that live in the 20-30 meters depth under the lake. Based on the phenotypic characters identified, the species is similar to $P$. binotatus, so it is identified as $P$. cf. binotatus. According to Champasri et al. (2007) and Collins et al. (2012), Silver Barb or Spotted Barb are the common names of Puntius, and they are sold for food and ornamental fish.

Based on molecular studies using the cytochrome $b$ gene (cyt b) mitochondrial DNA, Roesma (2011) and Roesma et al. (2016) reported that $P$. binotatus from several locations in West Sumatra reflected the complex and variable genetic and morphological characters among the locations and considered them as $P$. cf. binotatus. Vitri et al. (2012) reported that $P$. binotatus from six populations consisting of five rivers (Salibutan, Batang Kuranji, Sungai Asam, Batang Gumanti and Batang Sinamar) and one lake (Lake Maninjau) in West Sumatra showed significant morphological differences among the locations. Recent study, Karlina et al. (2016) using cyt b gene on $P$. cf. binotatus from Gunung Tujuh Lake and P. cf. Binotatus recommended that $P$. cf. binotatus from Gunung Tujuh Lake as a candidate of a new species.

According to Kottelat (2013), Puntius and Barbodes are synonymous. Previously Taki et al. (1978), Mohsin and Ambak (1983), and Rainboth (1996) used the Barbonymus, Barbus, Barbodes, Systomus, Capoeta, and Hypsibarbus as the generic names. Roesma et al. (2018) reported those genera are not synonym and $P$. cf. binotatus is suggested as Barbodes banksi from West Sumatra that consist of at least three subspecies based on Cytochrome Oxidase-I (COI) gene. Based on the previous studies, it is crucial to use CO1 gene to identify and verify the taxonomic status of Silver Barb ( $P$. cf. binotatus) from Gunung Tujuh Lake. A mtDNA gene has been widely used for taxonomic, phylogenetic and phylogeography studies in the Silver Barb (John et al. 2013; Singh et al. 2013; Negi et al. 2017). The COI gene is a part of mtDNA used for species identification (DNA barcode). The DNA barcode is designed to develop a rapid species identification that also allows detecting new species (Hebert et al. 2003a; Stoeckle 2003; Hebert and Gregory 2005). COI gene has rapid evolutionary rates than other mtDNA genes. Therefore, is useful for identification at species level, and has been applied to identify numerous animal taxa (Hebert et al. 2003a; Clare et al. 2006; Hajibabaei et al. 2007; Smith et al. 2008; Frezal and Leblois 2008). 


\section{MATERIAL AND METHODS}

A total of 50 individuals of $P$. cf. binotatus in Gunung Tujuh Lake, Kerinci District, Jambi Province, Indonesia were collected following Cailiet et al. (1986). A piece of the tissue samples collected from individuals and stored in Eppendorf tubes $(1.5 \mathrm{~mL})$ containing $96 \%$ ethanol PA. Individual samples were temporarily stored in $10 \%$ formalin and transferred in $70 \%$ ethanol for long-term storage. Morphological measurements were done for 29 morphometric and 17 meristic characters following Kottelat et al. (1993) and Haryono and Tjakrawidjaja (2006) with additional three characters: Lenght of upper caudal (LUCL), Lenght of lower caudal (LLCL) and Lenght of middle caudal (LMCL). Morphometric and meristic characters were measured using digital calipers to the nearest $0.1 \mathrm{~mm}$.

Total genomic DNA was extracted using Invitrogen PureLink $^{\mathrm{TM}}$ Genomic DNA Mini Kit. The result of DNA extraction was used for Polymerase chain reaction (PCR) amplification using thermal cycler (SensoQuest). PCR was conducted in $25 \mu \mathrm{l}$ volumes containing 2x MyTaq Hs Red Mix (Bioline), $0.01 \mathrm{mM}$ forward and reverse primer, 35 ng/ $\mu \mathrm{l}$ DNA template and $10 \mu \mathrm{l}$ nuclear-free water. Primer used were forward (Fish F1: 5'TCAACCAACCACAAA GACATTGG CAC3') and reverse (Fish R1: 5'TAGACTTCTGGGTGGCCAAAGAATCA3') (Ward et al. 2005). The optimal PCR condition consisting of initial denaturation at $95^{\circ} \mathrm{C}$ for 2 minutes, 35 cycles consisting of denaturation at $94^{\circ} \mathrm{C}$ for 30 seconds, annealing at $54^{\circ} \mathrm{C}$ for
30 seconds, elongation at $72^{\circ} \mathrm{C}$ for 1 minute and a final extension at $72^{\circ} \mathrm{C}$ for 10 minutes. The PCR products were visualized in $2 \%$ agarose at 100 Volt, $20 \mathrm{~W}$ for $50 \mathrm{~min}$. Good quality PCR product was used as samples for sequencing, performed in MacroGen USA DNA Sequencing Laboratory.

A total of 46 sequences of COI gene were analyzed consisted of four sequences Puntius cf. binotatus in Gunung Tujuh Lake, 17 sequences $P$. cf. binotatus of other populations in Sumatra and 25 sequences taken from Genbank NCBI included outgroup species (Rasbora daniconius, Danio choprai, and Botia rostrata) (Table 1). DNA sequences (forward and reverse) were assembled and edited using the DNA STAR program (Burland 2000). DNA sequence of $P$. cf. binotatus compared with the sequences contained in NCBI, to check the similarity of all sequences in http: //blast.ncbi.nlm.nih.gov/Blast.cgi. All sequences were aligned using the Clustal $\mathrm{X}$ program (Thompson 1997). The aligned sequences were edited using BIOEDIT program (Hall 1999). The number of polymorphic sequences was analyzed using the DNA Sequence Polymorphism 5.10 (Rozas 2003). Sequence divergences of all sequences were analyzed using the Kimura-2 parameter model (K2P) in the MEGA 6.0 program (Tamura 2013). The phylogenetic tree was reconstructed based on four methods; Neighbors Joining (NJ), Maximum Evolution (ME), Maximum Likelihood (ML) and Maximum Parsimony (MP) using MEGA 6.0 (Tamura 2013).

Table 1. List of freshwater fish species barcoded along with GenBank Accession Numbers

\begin{tabular}{|c|c|c|c|c|c|}
\hline Family & Genus & Species & Location & Accession No. & Sources \\
\hline \multirow[t]{24}{*}{ Cyprinidae } & Puntius & Puntius binotatus & Lampung & JQ665834 & Wibowo et al. (2012) \\
\hline & & Puntius binotatus & Malaysia & JN646096 & Sade and Biun (2012) \\
\hline & & Puntius banksi & Malaysia & JF781235 & Song et al. (2013) \\
\hline & & Puntius sophore & India & JX983465 & Khedkar et al. (2014) \\
\hline & & Puntius denisonii & India & HQ176003 & Lakra et al. (2010) \\
\hline & & Puntius orphoides & & JF915642 & Collins et al. (2011) \\
\hline & & Puntius sarana & India & EU417805 & Lakra et al. (2008) \\
\hline & & Puntius sarana & India & JQ667570 & Khedkar et al. (2014) \\
\hline & & Puntius sarana subnasutus & & HE664122 & Vincent (2012) \\
\hline & Barbodes & Barbodes binotatus & Malaysia & KT001028 & Meganathan et al. (2015) \\
\hline & & Barbodes binotatus & Thailand & KP263421 & Panprommin and Chanto (2014) \\
\hline & Systomus & Systomus sarana & India & JX983454 & Khedkar et al. (2014) \\
\hline & & Systomus sarana & India & KJ476776 & Lal et al. (2014) \\
\hline & & Systomus orphoides & Thailand & KP263417 & Panprommin and Chanto (2014) \\
\hline & Barbus & Barbus matthesi & Afrika & KR153301 & Sakharova (2015) \\
\hline & & Barbus camptacanthus & Afrika & HM418123 & iBOL (2010) \\
\hline & & Barbus callipterus & Afrika & HM418124 & iBOL (2010) \\
\hline & & Barbus brazzai & Afrika & KT193523 & Decru et al. (2015) \\
\hline & Barbonymus & Barbonymus schwanenfeldii & Malaysia & KT001008 & Meganathan et al. (2015) \\
\hline & & Barbonymus schwanenfeldii & Laos & JQ346171 & Pasco-Viel et al. (2012) \\
\hline & & Barbonymus altus & Afrika & KU568767 & Van Der Walt et al. (2012) \\
\hline & & Barbonymus gonionotus & Philipina & HQ682667 & Aquino et al. (2011) \\
\hline & Rasbora & Rasbora daniconius & India & JX983478 & Khedkar et al. (2012) \\
\hline & Danio & Danio choprai & Myanmar & KX852477 & Kullander and Noren (2016) \\
\hline Botiidae & Botia & Botia rostrata & China & KM610433 & Chen et al. (2015) \\
\hline
\end{tabular}




\section{RESULT AND DISCUSSION}

The morphological characters of Puntius cf. binotatus in Gunung Tujuh Lake were similar to Punitus binotatus described by Weber and de Beaufort (1916); Roberts (1989 and Kottelat et al. (1993)). The characters that distinguish $P$. cf. binotatus in Gunung Tujuh Lake and $P$. binotatus from other area are the absence of a black spot on the base of the anterior dorsal ray and in the part of the body. According to Vitri et al. (2012), ten morphological characters of $P$. binotatus in West Sumatra were different significantly (Table 2), and also showed the morphological variations at a different altitude.

The total size of the COI gene is $720 \mathrm{bp}$ and $564 \mathrm{bp}$ of them were successfully amplified. The average of nucleotide composition was of A: $27.30 \%, \mathrm{C}: 27.20 \%$, T: $29.40 \%$, and G: $16.10 \%$. The nucleotide composition was similar to previous studies (Negi et al. 2017; Roesma et al. 2018). The frequency of distributions for the four nucleotide bases was significantly different, with nonoverlapping confidence intervals. The proportion of pyrimidines $(\mathrm{T}, \mathrm{C})$ to purines $(\mathrm{A}, \mathrm{G})$ deviated from a 50:50 ratio is well described in the literature for protein-coding genes (Kartavtsev et al. 2009). The bias of the nucleotide bases reflects the hydrophobic properties of the encoded proteins (Nailor et al. 1996). The A $+\mathrm{T}$ content $(56.70 \%)$ in present study higher than $\mathrm{G}+\mathrm{C}(43.30 \%)$. Those values indicate the characteristic of the mitochondrial DNA of all classes of fishes (Johns and Avise 1998; Kartavtsev et al. 2007; Kartavtsev et al. 2011; Xiao et al. 2012; Negi et al. 2017).

Of the $564 \mathrm{bp}$ COI gene sequences, 352 bp (62.41\%) was conserved sites, and 212 bp (37.59\%) was the variable site without insertion or deletion. In the total of 212 variable sites, $183 \mathrm{bp}(86.32 \%)$ are parsimony informative site, and 29 bp (13.68\%) are singleton site. In total, there were 337 mutations in all sequences, the transitions are more common than transversion, as found in animal mitochondrial genomes (Briolay et al. 1998). The bias value of transition and transversion ratio (Ts; Tv) is R: 7.208. P. cf. binotatus from Sumatra showed 71 substitutions which consist of 62 transitions and nine transversions without insertion and deletion. The COI gene is representing 188 amino acids for all samples. Among all of the mutations were observed in P. cf. binotatus of Sumatra, change has occurred only in one amino acid that is in the 172nd amino acid $(\mathrm{I} \rightarrow \mathrm{V})$. The calculated nucleotide diversity ( $p i)$ in the 46 sequences was of 0.11608 , Notably, for $P$. cf. binotatus in Sumatra, the nucleotide diversity (pi) was 0.04650 , that value is at the middle level when compared to the other reported species of Puntius (Negi et al. 2017). The value indicated that in Sumatra, there are $P$. cf. binotatus which vary genetically.

Four phylogenetic methods (ME/NJ/ML/MP) were used to construct the phylogenetic tree (Figure 1) The topologies of ML tree was similar to NJ, ME and MP using 1000 bootstrap replicates. Two main clusters were obtained, supported by high bootstrap value of 97/98/95/96 for $\mathrm{ME} / \mathrm{NJ} / \mathrm{ML} / \mathrm{MP}$, respectively. The first cluster consists of five subclusters and the second cluster consists of four subclusters. All the members in the second cluster are the genus that considered as a synonym to Puntius (Barbus, Barbonymus, Puntius, and Systomus). The sequence divergences that separate the first and second cluster was of $14.2-20.4 \%$. When referring to sequence divergence value reported by Kartavtsev et al. (2007) and Kartavtsev et al. (2011), all the member of the first cluster cannot be considered Puntius. The sequence divergences between $P$. cf. binotatus in Gunung Tujuh Lake with other $P$. cf. binotatus in Sumatra were of $3.1-7.4 \%$.

In the first subcluster of the topology, $P$. cf. Binotatus Gunung Tujuh Lake is in the same cluster with $P$. cf. binotatus from Diatas lakes, Batang Lembang, Batang Gumanti, Muara Pingai rivers, and P. banksi from Malaysia.

Table 2. Morphometric measurements of Puntius cf. binotatus in Gunung Tujuh Lake, Kerinci, Jambi, Indonesia

\begin{tabular}{|c|c|c|c|c|c|c|c|}
\hline \multirow[t]{2}{*}{ Characteristics } & \multirow[t]{2}{*}{ Code } & \multicolumn{3}{|c|}{ Range $(\mathrm{mm}) \mathrm{n}=50$} & \multicolumn{3}{|c|}{ \%Standar Length (SL) } \\
\hline & & $\operatorname{Max}$ & Min & Mean \pm SD & Max & Min & Mean \pm SD \\
\hline Total length & TL & 80.54 & 49.2 & $61.90 \pm 7.12$ & 147.24 & 105.56 & $129.36 \pm 5.28$ \\
\hline Standard length & SL & 62.83 & 37.7 & $47.93 \pm 5.96$ & - & - & - \\
\hline Head length & $\mathrm{HL}$ & 18.22 & 11.2 & $14.08 \pm 1.54$ & 40.02 & 25.26 & $29.51 \pm 2.35$ \\
\hline Head Depth & HD & 12.16 & 6.95 & $9.73 \pm 1.10$ & 30.30 & 14.44 & $20.42 \pm 2.26$ \\
\hline Head Width & HW & 10.52 & 4.87 & $7.11 \pm 1.05$ & 20.55 & 11.95 & $14.88 \pm 1.69$ \\
\hline Eye Diameter & ED & 4.15 & 2.07 & $2.89 \pm 0.34$ & 8.23 & 4.03 & $6.09 \pm 0.84$ \\
\hline Interorbital width & IW & 5.96 & 3.43 & $4.76 \pm 0.58$ & 14.95 & 7.69 & $9.99 \pm 1.20$ \\
\hline Mouth Length & ML & 27.1 & 1.42 & $2.67 \pm 3.54$ & 53.01 & 2.95 & $5.55 \pm 6.90$ \\
\hline Interorbital length & IOL & 14.6 & 8.92 & $10.94 \pm 1.27$ & 25.68 & 19.01 & $22.89 \pm 1.43$ \\
\hline Snout of length & SNL & 23.39 & 2.46 & $6.24 \pm 4.15$ & 54.06 & 6.02 & $13.20 \pm 9.44$ \\
\hline Body Depth & $\mathrm{BD}$ & 17.08 & 4.99 & $9.67 \pm 3.72$ & 33.64 & 10.67 & $20.14 \pm 7.13$ \\
\hline Body Width & BW & 20.43 & 4.44 & $10.81 \pm 3.98$ & 34.94 & 10.85 & $22.60 \pm 8.00$ \\
\hline Caudal Peduncle Length & CPL & 11.39 & 6.24 & $8.78 \pm 1.04$ & 29.13 & 13.42 & $18.45 \pm 2.38$ \\
\hline Dorsal Base Length & DBL & 8.68 & 4.12 & $6.74 \pm 0.95$ & 18.40 & 10.06 & $14.13 \pm 1.77$ \\
\hline Dorsal Fin Height & DFH & 13.96 & 7.27 & $9.96 \pm 1.46$ & 32.32 & 15.62 & $20.92 \pm 3.01$ \\
\hline Ventral Fin Length & VFL & 10.79 & 5.1 & $7.97 \pm 1.21$ & 21.30 & 12.75 & $16.67 \pm 1.95$ \\
\hline Anal Fin Length & AFL & 9.42 & 4.97 & $7.03 \pm 0.92$ & 19.03 & 10.33 & $14.77 \pm 1.87$ \\
\hline
\end{tabular}


The sequence divergences between $P$. cf. binotatus Gunung Tujuh Lake and other members in that first subcluster are $3.1-4.1 \%$, supported with the highly bootstrap value (99/99/96/98 for ME/NJ/ML/MP, respectively). Sequence divergences between $P$. cf. binotatus Gunung Tujuh Lake and $P$. banksi from Malaysia was $4.1 \%$. Referring to the values reported by Ward et al. (2005), Kartavtsev et al. (2009), Kartavtsev (2011), and Kartavtsev (2013), this value places $P$. cf. binotatus Gunung Tujuh Lake is at the sub-species level. Based on Cyt b gene, Karlina et al. (2016) reported that the sequence divergences between $P$. cf. binotatus Gunung Tujuh Lake and others population $(P$. cf. binotatus from Diatas lakes, Batang Lembang, Batang Gumanti, Muara Pingai rivers and $P$. banksi from Malaysia) were $6.6-8.1 \%$ which positions it as a subspecies. Therefore both types of the genes provide the same conclusion that $P$. cf. binotatus Gunung Tujuh Lake is at the level of sub-species.

Puntius cf. binotatus Gunung Tujuh Lake is a sister taxon of $P$. cf. binotatus from other populations in the first subcluster. This closed relationship may be because of two group of fish live in the same geographical and ecological conditions. All populations of $P$. cf. binotatus in the first subcluster are located at the highland over 1.500 meters above sea level in the eastern part of Bukit Barisan Mountain range (Roesma et al. 2018). Bukit Barisan Mountain range is the row of the mountain that spreading out from northern to southern of Sumatra island more or less $1650 \mathrm{~km}$ in length. It is estimated that these conditions cause local adaptations to bring their current genetic variation. Negi et al. (2017) reported that $P$. sophree from the distinct region with the most homogeneous environment has low genetic diversity compared the populations from the small geographical region with a heterogeneous environment.

The sequence divergences between Puntius cf. binotatus Gunung Tujuh Lake and other members in the same subcluster with the member of the second subcluster (Barbodes binotatus Thailand with the accession number of KP263421 and Barbodes binotatus Malaysia with the accession number of KT001028) are 3.7-4.5\%. Consequently, $P$. cf. binotatus Gunung Tujuh Lake and other members in the first subcluster can be grouped in Barbodes because of the sequence divergences value do not support them to differ at genus levels. Besides the position of the branch in the tree, this provision also refers to Ward et al. (2005), Kartavtsev et al. (2009), Kartavtsev (2011), and Kartavtsev (2013).

The sequence divergences between the first and second subclusters in the first cluster with the member of the third subcluster (Puntius cf. binotatus Batang Kuranji River, $P$. cf. binotatus Batang Tarok River, and $P$. cf. binotatus Batang Tarok River) are 6.3-7.0\%. That value indicated that they are different at the subspecies level. Furthermore, the sequence divergences between the first, second, third subclusters in the first cluster with the member of the fourth subcluster are of $6.7-8.5 \%$. Those values also indicated that they are different the subspecies. All of the four subclusters have the sequence divergences value of $11.6-13 \%$ to $P$. binotatus Malaysia with the accession number of JN646096 in the fifth subcluster of the first cluster. Based on the values of Ward et al. (2005), Kartavtsev et al. (2009), Kartavtsev (2011), and Kartavtsev (2013), the range of $11.6-13 \%$ value shows that all of the four subclusters differ at the species level to P. binotatus Malaysia with the accession number of JN646096.

Puntius binotatus from Malaysia with the accession number JN646096 occupies the position at the cladogram that suggests it as the common ancestor to all of Puntius in Sumatra. In NCBI data Genbank, $P$. binotatus Malaysia with the accession number JN646096 and $P$. binotatus Lampung with the accession number JQ665834 listed as Barbodes binotatus while in the IUCN Red List the Barbodes binotatus stated as the accepted scientific/valid name of Puntius binotatus (Eschmeyer 2015; Jenkins et al. 2015; IUCN 2018). In addition, B. binotatus Thailand (KP263421), B. binotatus Malaysia (KT001028), and $B$. binotatus Lampung (JQ665834) cannot be classified as $P$. binotatus. Hence, all member of the first cluster is considered as the genus of Barbodes.

The genetic distance between Puntius banksi Malaysia (JF781235) and other members at same branch ( $P$. cf. binotatus Batang Gumanti River, $P$. cf. binotatus Diatas Lake, $P$. cf. binotatus Muaro Pingai River, and $P$. cf. binotatus Batang Lembang River) is ranged between $0.9 \%$ to $1.3 \%$, thus this group is identified as B. banksi. This results of this study implied that there are four subspecies of B. banksi in Sumatra. P. cf. binotatus Gunung Tujuh Lake is proposing as B. banksi gunungtujuh.

Studies by those of Kartavtsev and Lee (2006); Kartavtsev et al. (2007); Kartavtsev et al. (2009); Kartavtsev (2011); Kartavtsev et al. (2014) reported that the range of sequence divergences values of COI gene between $P$. cf. binotatus Gunung Tujuh and other Sumatra $P$. cf. binotatus was of 3.1-7.6\%, indicating differences at the subspecies level. However, a study by Karlina et al. (2016) using the Cyt b gene suggested a sequence divergence value of $6.6-11.2 \%$ indicating differences at different species levels. According to (Hebert et al. 2003a; Hebert et al. 2003b) the COI gene is more representative to be used to distinguish species. This support $P$. cf. binotatus Gunung Tujuh as a subspecies (B. banksi gunungtujuh). The second cluster consists of four sub-clusters consisted of genera that synonym of Puntius (Barbus, Barbodes, Systomus, and Barbonymus). This group is supported by high bootstrap values (98/97/95/97 for ME/NJ/ML/MP respectively). The sequence divergences between genera in the second cluster are $10.7-24.1 \%$ and with the first cluster is $13.7-21.1 \%$. These values show that they are different genus but the same family. At the second cluster of each genus that is considered a synonym of Puntius clustered on different sub-clusters, there are overlapping of placements in the Systomus and Puntius groups in the third subclasses. In the IUCN Red List, Fish Base and Catalog of life (Dahanukar 2010; Froese and Pauly 2018; IUCN 2018) the $S$. sarana and $S$. orphoides stated as the accepted scientific/valid name of $P$. sarana and $P$. orphoides. Therefore, the members of the third subcluster can be specified as Systomus group. 


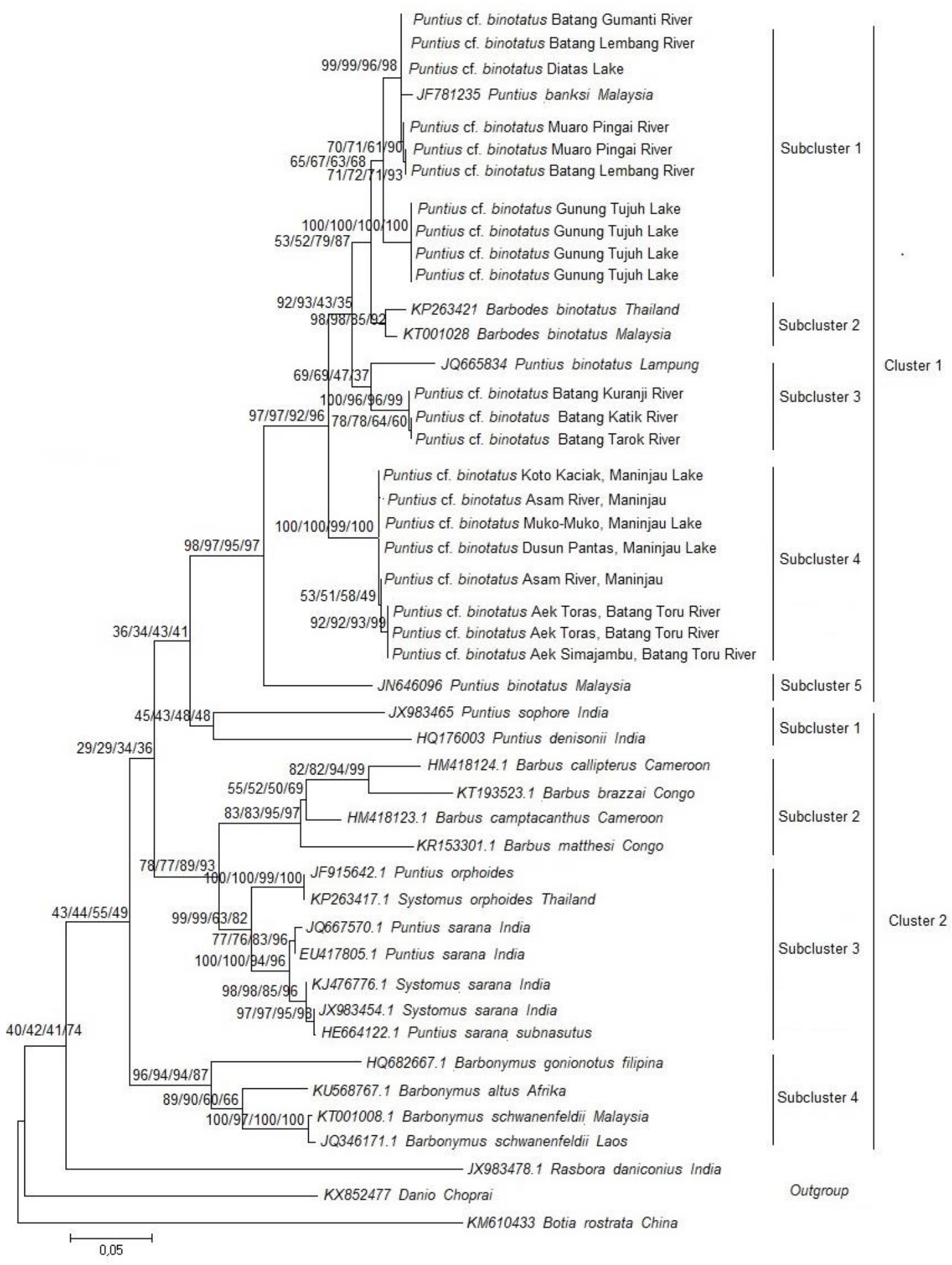

Figure 1. The ML phylogenetic tree of COI gene with bootstrapping of 1000 replicates (ME/ML/NJ/MP)

It is concluded that $P$. cf binotatus group in Sumatra can be considered as a Barbodes banksi that further consisted of four subspecies, one of them is $P$. cf. binotatus Gunung Tujuh Lake named as Barbodes banksi gunungtujuh. In the present phylogenetic tree, there is a clear separation or grouping of each different genus in the first cluster (Barbodes) and second cluster (Barbus, Puntius, Systomus, and Barbonymus). Moreover, the results of the analysis do not support the placement of Barbodes, Barbus, Systomus, and Barbonymus as synonyms of the Puntius. 


\section{ACKNOWLEDGMENTS}

The Authors thanks the Management of the Ministry of Research, Technology and Higher Education whose support the funding of the research to Andalas University. Our thanks also expressed to Biology Department of Andalas University for field and Laboratory work permit. We also would like to thank our students who helped us in sample collection and laboratory works in Genetic and Biomolecular Laboratory, Faculty of Mathematics and Sciences, Andalas University, Padang, Indonesia.

\section{REFERENCES}

Aquino LM, Tango JM, Canoy RJ, Fontanilla IK, Basiao ZU, Ong PS Quilang JP. 2011. DNA barcoding of fishes of Laguna de Bay, Philippines. Mitochond DNA 22 (4): 143-153.

Briolay J, Galtier N, Brito RM, Bouvet, Y. 1998. Molecular Phylogeny of Cyprinidae Inferred from cytochrome bDNA Sequences. Molecular Phylogenet Evol 9 (1): 100-108.

Burland TG. 2000. DNASTAR's Lasergene Sequence Analysis Software. Methods Mol Biol 132: 71-91.

Cailliet GM, Love MS, Ebeling AW. 1986. Fishes: A Field and Laboratory Manual on Their Structure, Identification, and Natural History. Waveland Press, Inc., Long Grove, IL.

Champasri T, Rapley R, Duangjinda M, Suksri A. 2007. A Morphologica Identification in Fish of the Genus Puntius Hamilton 1822 (Cypriniformes: Cyprinidae) of Some Wetlands in Northeast Thailand. Pak J Biol Sci 10 (24): 4383-4390.

Chen W, Ma X, Shen Y, Mao Y, He S. 2015. The fish diversity in the upper reaches of the Salween River, Nujiang River, revealed by DNA barcoding. Sci Rep 5: 17437.

Clare EB, Lim BK, Engstrom MD, Eger JL, Hebert PDN. 2006. DNA barcoding of Neotropical Bats: species identification and discovery within Guyana. Mol Ecol Notes 7: 184-190.

Collins RA, Yi Y, Meier R, Armstrong K. 2011. Barbs, barcodes, and biosecurity: identifying cyprinid fishes in the ornamental trade. National University of Singapore, Singapore.

Collins RA, Armstrong KF, Meier R, Yi Y, Brown SDJ, Cruickshank RH, Keeling S, Johnston C. 2012. Barcoding and border biosecurity: Identifying cyprinid fishes in the aquarium trade. PLoS ONE 7 (1): e28381. DOI: 10.1371/journal.pone.0028381.

Dahanukar N. 2010. Systomus sarana. The IUCN Red List of Threatened Species e.T166567A6237905. DOI: 10.2305/IUCN.UK.20104.RLTS T166567A6237905.en.

Decru E, Moelants T, De Gelas K, Vreven E, Verheyen E, Snoeks J. 2015 Taxonomic challenges in freshwater fishes: a mismatch between morphology and DNA barcoding in fish of the north-eastern part of the Congo basin. Mol Ecol Resour 16 (1): 342-352.

Eschmeyer WN. (ed.). 2015. Catalog of Fishes. Updated 2 October 2018. www.calacademy.org/scientists/projects/catalog-of-fishe

Frezal L, Leblois R. 2008. Four years of DNA barcoding: current advances and prospects. Infection, genetics, and evolution. J Mol Epidemiol Evol Genet Infect Dis 8: 727-736.

Froese R, Pauly D. (eds). 2018. FishBase (version Feb 2018). In: Roskov Y, Ower G, Orrell T, Nicolson D, Bailly N, Kirk PM, Bourgoin T, DeWalt RE, Decock W, Nieukerken EV, Zarucchi J, Penev L, eds. Species 2000 and ITIS Catalogue of Life, 30th October 2018. Digital resource at www.catalogueoflife.org/col. Species 2000: Naturalis, Leiden, the Netherlands.

Hajibabaei M, Singer GAC, Clare EL, Hebert PDN. 2007. Design and applicability of DNA arrays and DNA barcodes in biodiversity monitoring. BMC Biol 5: 1-15.

Hall, TA. 1999. BioEdit: A user-friendly biological sequence alignment editor and analysis program for Windows 95/98/NT. Nucleic Acid Symp Ser 41: 95-98.

Handika HA, Mursyid A, Chornelia A, Akbar MA, Karlina W, Roesma DI. 2014. Diversitas Ikan, Burung (Khusus Famili Timalidae) dan Mamalia kecil di Gunung Tujuh dan Masurai. Laporan Penelitian. Universitas Andalas, Padang. [Indonesian]
Haryono, Tjakrawidjaja AH. 2006. Morphological study for identification improvement of tambra fish (Tor Spp.: Cyprinidae) from Indonesia. Biodiversitas 7 (1) : 59-62.

Hebert PDN, Cywinska A, Ball SL, de Waard JR. 2003a. Biological identifications through DNA barcodes. Proc R Soc London B 270: 313-321.

Hebert PDN, Ratnasingham S, de Waard JR 2003b. Barcoding Animal Life: Cytochrome c Oxidase Subunit 1 Divergences among Closely Related Species Proc R Soc London B (Suppl.) 270: (S96-S99).

Hebert PDN, Gregory TR. 2005. TR: The promise of DNA barcoding for taxonomy. Syst Biol 54 (5): 852-859.

International Barcode of Life (iBOL). 2010. iBOL Data Release. www.gbif.org/search?q=Barbus

IUCN. 2018. The IUCN Red List of Threatened Species. Version 2018<http://www.iucnredlist.org >. ISSN 2307-8235

Jenkins A, Kullander FF, Tan HH. 2015. Barbodes binotatus. The IUCN Red List of Threatened Species 2015: e.T169538A70031333. DOI: 10.2305/IUCN.UK.2015-1.RLTS.T169538A70031333.en.

John L, Peter R, Gopalakrishnan A. 2013. Population structure of Denison's barb, Puntius denisonii (Pisces: Cyprinidae): a species complex endemic to the Western Ghats of India. J Phylogen Evol Biol 1: 106.

Johns GC, Avise JC. 1998. A comparative summary of genetic distance invertebrates from mitochondrial cytochrome b gene. Mol Biol Evol 15: 1481-1490.

Karlina W, Roesma DI, Tjong DH. 2016. Phylogenetic study of Puntius cf. binotatus fish from Gunung Tujuh Lake in Sumatera Based on Cytochrome b Gene. J Entomol Zool Stud 4 (2): 538-540.

Kartavtsev YP. 2013. Sequence Diversity at Cyt-b and Co-1 mtDNA Genes in Animal Taxa Proved Neo-darwinism. J Phylogenet Evol Biol 1(4):1-5

Kartavtsev YP, Lee JS. 2006. Analysis of nucleotide diversity at the cytochrome $\mathrm{b}$ and Cytochrome Oxidase-I genes at the population, species, and genus levels. Russ J Genet 42 (4): 341-362

Kartavtsev YP, Park TJ, Vinnikov KA, Ivankov VN, Sharina SN, Lee JS. 2007. Cytochrome b (Cyt-b) gene sequences analysis in six flatfish species (Pisces, Pleuronectidae), with phylogenetic and taxonomic insights. Mar Biol 152 (4): 757-773.

Kartavtsev YP, Sharina SN, Goto T, Balanov AA, Hanzawa, N. 2009. Sequence diversity at Cytochrome Oxidase-I (Co-1) gene among sculpins (Scorpaeniformes, Cottidae) and some other scorpionfish of Russia Far East with phylogenetic and taxonomic insights. Genes Genom 31 (2): 191-205.

Kartavtsev YP. 2011. Divergence at Cyt-b and Co-1 mtDNA genes on different taxonomic levels and genetics of speciation in animals. Mitochond DNA 3: 55-65.

Kartavtsev YP, Rozhkovan KV, Masalkova NA. 2014. Phylogeny based on two mtDNA genes (COI, Cytb) among Sculpins (Scorpaeniformes, Cottidae) and some other scorpionfish in the Russian Far East. Mitochond DNA 27: 2225-2240.

Khedkar GD, Jamdade R, Naik S, David L, Haymer D. 2014. DNA barcodes for the fishes of the Narmada, One of India's Longest Rivers. PLoS ONE 9 (7): E101460. DOI: 10.1371/journal .pone.0101460.

Kottelat M. 2013. The fishes of the inland waters of Southeast Asia: a catalogue and core bibliography of the fishes known to occur in freshwaters, mangroves and estuaries. Raffles Bull Zool 27:1-663.

Kottelat M, Whitten AJ., Kartikasari SN, Wiejoatmodjo S. 1993. Freshwater Fishes of Western Indonesia and Sulawesi. Periplus Eds. (HK) Ltd., Singapore.

Kullander SO, Noren M. 2016. Danio htamanthinus (Teleostei: Cyprinidae), a new species of miniature cyprinid fish from the Chindwin River in Myanmar. Zootaxa 4178 (4): 535-546.

Lakra WS, Verma MS, Goswami M. 2008. DNA Barcoding of Indian Freshwater Fishes. National Bureau of Fish Conservation Division, NBFGR,Uttar Pradesh, India.

Lakra WS, Goswami M, Yadav K. 2010. Development and characterization of cell lines from Denison's barb. National Bureau of Fish Conservation Division, NBFGR,Uttar Pradesh, India.

Lal KK, Mohindra V, Singh RK, Dhawan S, Chandra S, Gupta BK, Dwivedi AK, Jena JK. 2014. Molecular characterization of Indian freshwater Cyprinids using cytochrome C Oxidase I sequences. National Bureau of Fish Conservation Division, NBFGR,Uttar Pradesh, India. 
Meganathan P, Austin CM, Tam SM, Chew PC, Siow R, Rashid AZ Song BK. 2015. An application of DNA barcoding to the Malaysian freshwater fish fauna: mtDNA COI sequences reveal nove haplotypes, cryptic species, and field-based misidentification. Monash University Malaysia, Selangor, Malaysia.

Mohsin AKM, Ambak, MA. 1983. Freshwater fishes of Peninsular Malaysia. University Pertanian Malaysia, Malaysia.

Nailor GJ, Collins TM, Brown WM. 1996. Hydrophobicity and phylogeny. Nature 373: 565-566.

Negi RK, Joshi BD, Johnson JA, De R, Goyal SP. 2017. Phylogeography of freshwater fish Puntius sophore in India. Mitochond DNA 29: 256-265.

Panprommin D, Chanto W. 2014. Fish species diversity and identification using DNA barcode in Than. Sawan Waterfall, Doi Phu Nang national park, Phayao province. Phayao University, Phayao, Thailand.

Pasco-Viel E, Veran M, Viriot L. 2012. Bleeker was right: Revision of the genus Cyclocheilichthys (Bleeker 1859) and resurrection of the genus Anematichthys (Bleeker 1859), based on morphological and molecular data of Southeast Asian Cyprininae (Teleostei, Cypriniformes). Zootaxa 3586: 41-54.

Rainboth, WJ. 1996. Fishes of the Cambodian Mekong FAO Species Identification Field Guide of Fishery Purpose. Rome: Food and Agriculture Organization: 1-265.

Roberts TR. 1989. The Freshwater Fishes of Western Borneo (Kalimantan Barat, Indonesia). California Academy of Sciences 14: 1-210.

Roesma DI. 2011. Diversitas Species dan Kekerabatan Genetik Ikan-Ikan Cyprinidae di Danau-Danau dan Sungai-Sungai di Sekitarnya Di Kawasan Sumatera Barat. Disertasi. Universitas Andalas, Padang. (Species Diversity and Genetic Relationship of Cyprinidae in Lakes and the Adjoining Rivers in West Sumatra. Dissertation. Andalas University, Padang). [Indonesian]

Roesma DI, Chornelia A, Mursyd A, Kamsi M. 2016. Short Communication: Fish diversity of the Batang Toru River System, South Tapanuli, North Sumatra. Biodiversitas. 17 (2): 628-634

Roesma DI, Djong HT, Munir W, Agesi AV, Chornelia A. 2017. Genetic diversity of Tor douronensis (Pisces: Cyprinidae) in West Sumatra, Indonesia Biodiversitas 18 (3): 1018-1025.

Roesma DI, Djong HT, Munir W, Aidil DR. 2018. New Record Species of Puntius (Pisces: Cyprinidae) from West Sumatra Based on Cytochrome Oxidase I Gene. International Journal on Advanced Science Engineering Information Technol 8 (1): 250-256.

Rozas J, Sanchez-Del Barrio JC, Messeguer X, Rozas R. 2003. DNA SP, DNA polymorphism analyses by coalescent and other methods. Bioinformatics 19: 2496-2497.

Sade A, Biun, H. 2012. The Ichthyofauna of Maliau Basin Buffer Zone at Maliau Basin. Conservation Area, Sabah, Malaysia. J Trop Bio Conserv 9 (1): 105-113.
Sakharova H. 2015. Barbin cyprinids of the Kwilu River (Democratic Republic of Congo) with a description of a new species of Clypeobarbus. Democratic Republic of Congo, Afrika.

Singh NS, Behera BK, Sharma AP. 2013. Population Structure of Puntius sophore Inferred from Variation in Mitochondrial DNA Sequences. International J Research in Fisheries and Aquaculture 3 (3): 112-115.

Smith MA, Rodriguez JJ, Whitfield JB, Deans AR, Janzen DH. 2008. Extreme diversity of tropical parasitoid wasps exposed by iterative integration of natural history, DNA barcoding, morphology, and collections. Proc Natl Acad Sci USA 105: 12359-12364.

Song LM, Munian K, Abd Rashid Z, Bhassu, S. 2013. Characterization of Asian Snakehead Murrel Channa striata (Channidae) in Malaysia: An Insight into Molecular Data and Morphological Approach. The Scientific World Journal. DOI: 10.1155/2013/917506.

Stoeckle M. 2003. Taxonomy, DNA and the barcode of life. Bio Sci 53: 796-797.

Taki Y, Katsuyama A, Urushido T. 1978. Comparative Morphology and Interspecific Relationships Of The Cyprinid Genus Puntius. Japanese J Ichthyol 25: 1-8

Tamura K, Stecher G, Peterson D, Filipski A, Kumar S. 2013. MEGA 6: molecular evolutionary genetics analysis version 6.0. Mol Biol Evol 30: $2725-2729$.

Thompson JD, Gibson TJ, Plewniak F, Jeanmougin F, Higgins DG. 1997. The Clustal $\mathrm{X}$ windows interface flexible strategies for multiple sequence alignment aided by quality analysis tools. Nucleic Acids Research 24: 4876-4882.

Van Der Walt KA, Makinen T, Weyl O, Collins R, Swartz E. 2012. DNA barcoding of ornamental freshwater fish from South Africa. South African Institute for Aqutic Biodiversity, Eastern Cape, South Africa.

Vincent M. 2012. Visual and olfactory perception in the reproduction of a cyprinid. Fish P. parrah Day. [Thesis]. Calicut University, Mallapuram. [Indian]

Vitri DK, Roesma DI, Syaifullah. 2012. (Morphological Analysis of $P$. binotatus Valenciennes 1842 (Pisces: Cyprinidae) from several locations in West Sumatra. Jurnal Biologi Universitas Andalas 1 (2): 139-143.

Ward RD, Zemlak TS, Innes BH, Last PR, Hebert PDN. 2005. DNA barcoding Australia's fish species. Philos Trans R Soc B 360: 18471857

Weber MG, de Beaufort LF. 1916. Fishes of the Indo-Australian Archipelago Vol. III. E.J. Brill, Leiden.

Wibowo A, Farajalah A, Husnah H. 2012. DNA barcoding of freshwater fish species of Manna River (Bengkulu) and Semanka River (Lampung). Indonesia Fish Res J 19 (1): 9-17.

Xiao B, Chen AH, Zhang YY, Jiang GF, Hu CC, Zhu CD. 2012. Complete mitochondrial genomes of two cockroaches, Blattella germanica and Periplaneta americana, and the phylogenetic position of termites. Curr Genet $58(2) \cdot 65-77$. 